\title{
Review Article \\ Steroid Hormone Receptor Signals as Prognosticators for Urothelial Tumor
}

\author{
Hiroki Ide and Hiroshi Miyamoto \\ Departments of Pathology and Urology, Johns Hopkins University School of Medicine, Baltimore, MD 21287, USA \\ Correspondence should be addressed to Hiroshi Miyamoto; hmiyamol@jhmi.edu
}

Received 18 September 2015; Accepted 18 November 2015

Academic Editor: Ja Hyeon Ku

Copyright ( $) 2015$ H. Ide and H. Miyamoto. This is an open access article distributed under the Creative Commons Attribution License, which permits unrestricted use, distribution, and reproduction in any medium, provided the original work is properly cited.

\begin{abstract}
There is a substantial amount of preclinical or clinical evidence suggesting that steroid hormone receptor-mediated signals play a critical role in urothelial tumorigenesis and tumor progression. These receptors include androgen receptor, estrogen receptors, glucocorticoid receptor, progesterone receptor, vitamin D receptor, retinoid receptors, peroxisome proliferator-activated receptors, and others including orphan receptors. In particular, studies using urothelial cancer tissue specimens have demonstrated that elevated or reduced expression of these receptors as well as alterations of their upstream or downstream pathways correlates with patient outcomes. This review summarizes and discusses available data suggesting that steroid hormone receptors and related signals serve as biomarkers for urothelial carcinoma and are able to predict tumor recurrence or progression.
\end{abstract}

\section{Introduction}

Bladder cancer, which is mostly urothelial carcinoma, is one of the most frequently diagnosed neoplasms, with estimated 429,800 new cases and 165,100 deaths which occurred in 2012 worldwide [1]. Patients with superficial urothelial tumor suffer from its recurrence with occasional progression to muscle invasion after transurethral surgery. In contrast, those with muscle-invasive tumor often develop disease progression or metastatic tumor despite more aggressive treatment. Cystoscopy which is an invasive and relatively expensive procedure is the "gold standard" for the detection of bladder cancer [2-4]. Urine cytology is a highly specific, noninvasive adjuvant test widely utilized with cystoscopy for both screening/initial diagnosis of bladder cancer and surveillance of tumor recurrence [5]. There are also several urine-based markers/tests, such as nuclear matrix protein 22 (NMP22), bladder tumor antigen (BTA), and UroVysion, which are useful for detecting urothelial tumors and may thus be substitutes of cystoscopy and/or cytology [6-9]. However, none of these markers or tests have demonstrated a significant association with prospective tumor recurrence or disease progression in patients with urothelial cancer.
Epidemiological and clinical studies have indicated that men have a significantly higher risk of bladder cancer, whereas women tend to have more aggressive tumors [ 1 , 10-15]. These observations have prompted investigations of steroid hormones and their receptor signals, especially androgens/estrogens and androgen/estrogen receptors (AR/ER), in bladder cancer, which have demonstrated their critical roles in tumorigenesis and tumor progression [16-18]. Accordingly, bladder cancer is now considered as an endocrinerelated neoplasm. Additionally, studies have identified a variety of molecules or pathways regulated by steroid hormones and their receptor signals in bladder cancer cells. These findings have also provided novel therapeutic targets for urothelial carcinoma.

Recent evidence has thus indicated the involvement of nuclear receptor-mediated signals in urothelial cancer outgrowth. These receptors include AR, ER $\alpha, \mathrm{ER} \beta$, glucocorticoid receptor (GR), progesterone receptor (PR), vitamin $\mathrm{D}$ receptor (VDR), retinoid receptors (e.g., retinoic acid receptor (RAR) and retinoid X receptor (RXR)), and peroxisome proliferator-activated receptors (e.g., PPAR $\gamma$ ) as well as orphan receptors. More importantly, recent studies have assessed the prognostic significance of steroid hormone 
receptor signals and related pathways in urothelial tumors. In this paper, we mainly review immunohistochemical studies showing associations between alterations of steroid hormone receptors in urothelial tumors and patient outcomes. Furthermore, we highlight several molecules regulated by AR and/or ER signals in bladder cancer cells, which may contribute to the development of diagnostic and/or prognostic biomarkers.

\section{Androgens and $A R$}

Using cell line and animal models, androgens have been shown to promote urothelial carcinogenesis and cancer progression via the AR pathway $[16,17,19-26]$. Specifically, androgen deprivation inhibited tumor development in male rodents treated with a bladder carcinogen $N$-butyl- $N$-4hydroxybutyl nitrosamine (BBN) [21, 23]. Furthermore, $\mathrm{BBN}$ completely failed to induce bladder cancer in $\mathrm{AR}$ knockout mice [23]. AR signals have also been found to downregulate the expression of P450 CYP4B1 [27], UDPglucuronosyltransferases (UGTs) [28], and GATA3 [29], all of which are known to prevent urothelial tumorigenesis. Meanwhile, androgen deprivation resulted in inhibition of bladder cancer cell proliferation and invasion [23-26, 30-33]. Recent clinical studies have also suggested that androgen deprivation therapy for prostate cancer prevents bladder cancer development [34] and recurrence [35].

Immunohistochemical studies have demonstrated that the positive rates of AR expression in bladder or upper urinary tract (UUT) urothelial tumors range from $13 \%$ to $55 \%$, which is significantly lower than that in nonneoplastic urothelial tissues [25, 30, 36-46] (Table 1). However, two studies showed no AR expression in normal urothelium [30, 43]. Similarly, most of the studies showed downregulation of AR expression in high-grade and muscle-invasive tumors, compared with low-grade and non-muscle-invasive tumors, respectively [25, 30, 36, 39-41, 45].

Prognostic significance of AR expression in urothelial tumors remains controversial. Despite the promoting effects of AR signals on tumorigenesis, two studies showed a significant correlation [44] and a tendency [30], respectively, between AR expression and lower risks of bladder tumor recurrence. In contrast, AR expression correlated with the progression of bladder tumors [40,43], while others did not reveal its prognostic significance in patients with bladder cancer. Additionally, none of the immunohistochemical analyses in UUT tumors have demonstrated strong correlations of AR expression with their outcomes.

\section{Estrogens and ERs}

Both stimulatory and inhibitory effects of estrogens on urothelial cancer outgrowth, which appear to be cell-specific and dependent on the functional activity of $\operatorname{ER} \alpha$ and $\operatorname{ER} \beta$, have been documented [16, 18-20, 47-50]. For instance, significantly higher incidence of bladder cancer was observed in $\mathrm{BBN}$-treated $\mathrm{ER} \alpha$ knockout female mice, compared with wild-type female littermates, suggesting the preventive role of $\mathrm{ER} \alpha$ in bladder cancer development [51]. Selective ER modulators, such as tamoxifen and raloxifen, were also shown to inhibit the growth of bladder cancer cell lines expressing ER $\beta$ $[47,49]$. Nonetheless, estrogens promoted the cell proliferation of a urothelial cancer line predominantly via the ER $\alpha$ pathway as well as that of primary urothelium line predominantly via the $\operatorname{ER} \beta$ pathway [50].

Immunohistochemistry has detected ER $\alpha$ protein only in a small subset (e.g., 1-5\%) of bladder cancer specimens $[43,52-54]$ (Table 1). Of note, in a study using a quantitative polymerase chain reaction (PCR) method, ER $\alpha$ gene was found to be positive in all the 10 tumors examined, which was even stronger (2.77-fold) than in matched normal tissues [50]. Our immunohistochemical analyses showed higher positive rates in bladder (27\% [40]) and UUT (18\% [46]) tumors, compared with those in other studies described above. In contrast to the findings in PCR analysis [50], elevated levels of ER $\alpha$ protein expression were detected in nonneoplastic urothelium, compared with urothelial cancer $[40,46,53]$. At least two of the immunohistochemical studies also demonstrated that $\operatorname{ER} \alpha$ expression was downregulated in higher grade or stage tumors $[40,53]$. However, no studies have identified the prognostic values of ER $\alpha$ in patients with urothelial tumor.

$\mathrm{ER} \beta$ protein expression was reported to be positive in $22-76 \%$ of urothelial tumors, which was significantly lower than the positive rates in nonneoplastic urothelial tissues, in some of the studies [30, 40, 41, 46, 52, 55, 56] (Table 1). More recently, Tan et al. [54] demonstrated that all the 410 bladder tumors examined were immunoreactive for ER $\beta$. There was significant upregulation $[40,44,52,55]$ or downregulation [56] of ER $\beta$ expression seen in higher grade or more invasive tumors. Elevated $\mathrm{ER} \beta$ expression in bladder cancers was also found to correlate with higher risks of tumor recurrence and/or progression $[30,40,57]$, and $\operatorname{ER} \beta$ positivity was an independent predictor of tumor progression [30]. Conversely, a strong association between $\operatorname{ER} \beta$ overexpression and favorable prognosis was demonstrated $[44,54]$.

\section{Glucocorticoids and GR}

The relationship between glucocorticoids and urothelial tumorigenesis is debatable. A population-based case-control study showed that prolonged oral glucocorticoid use was at an increased risk of developing bladder cancer [58], presumably due to immunosuppression. In contrast, our preclinical studies have revealed that glucocorticoids directly mediate GR activity in bladder cancer cells and that GR functions as a tumor suppressor $[59,60]$. Natural or synthetic glucocorticoids, such as corticosterone, prednisone, and dexamethasone, strongly inhibited bladder cancer cell invasion and metastasis via inactivating nuclear factor- (NF-) $\kappa \mathrm{B}$. However, treatment with dexamethasone resulted in an increase in bladder cancer cell viability and a decrease in apoptosis particularly that was induced by a cytotoxic agent, cisplatin, suggesting induction of chemoresistance by glucocorticoids. It is thus likely that GR signals, apart from glucocorticoidinduced immunosuppression, have dual roles in bladder cancer: suppression of tumor progression versus induction of cell proliferation. It should also be mentioned that the action of glucocorticoids is often complex and is generally dependent on a balance of transactivation and transrepression of GR 


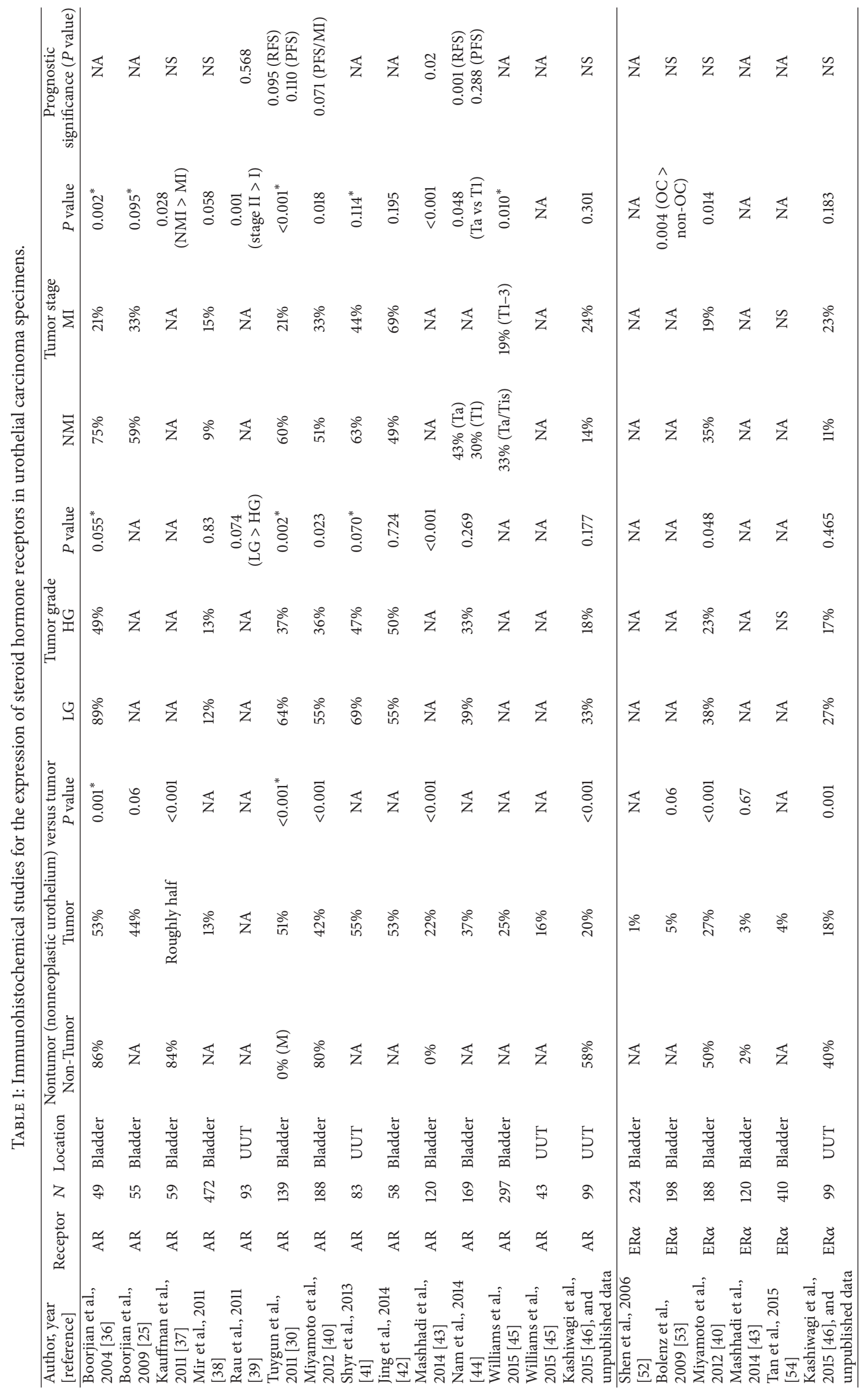




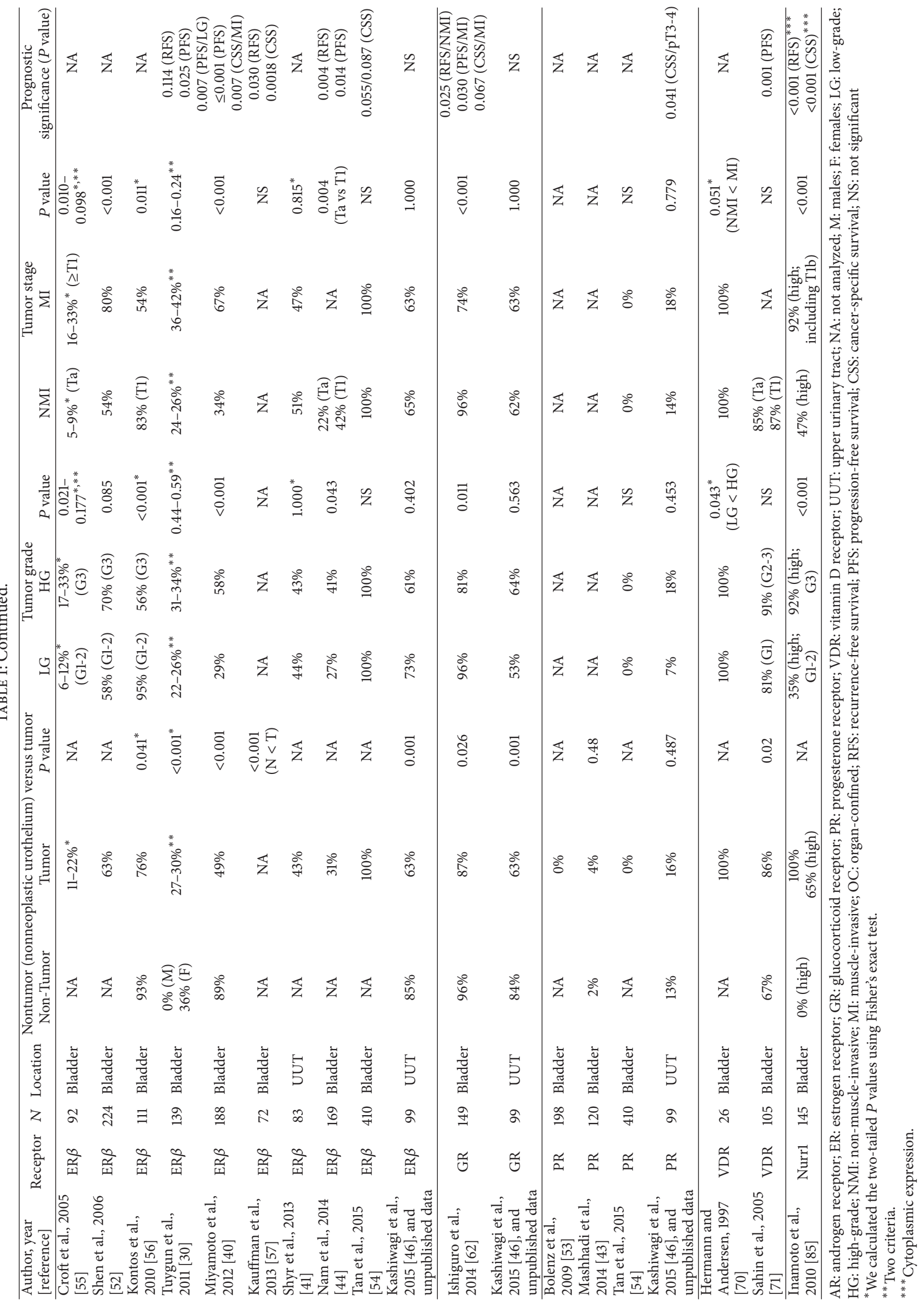


that involve therapeutic effects of glucocorticoids and adverse effects associated with glucocorticoid therapy, respectively. Recently, we found that compound A, a plant derivative known to function as a GR agonist as well as an AR antagonist, induced only GR transrepression in bladder cancer cells and more efficiently inhibited tumor growth than dexamethasone or an antiandrogen flutamide [61].

Our immunohistochemical studies in bladder [62] and UUT [46] tumors showed that most of nonneoplastic urothelial tissues expressed the GR, which was downregulated in urothelial neoplasms (Table 1). GR expression was also significantly reduced in high-grade or muscle-invasive bladder tumors, compared with low-grade or non-muscle-invasive tumors [62]. However, this was not seen in UUT tumors [46]. In addition, loss of GR expression was found to correlate with recurrence of non-muscle-invasive bladder tumors and progression of muscle-invasive bladder tumors in univariate analyses [62]. Multivariate analysis identified low GR expression as a predictor for recurrence of non-muscle-invasive bladder tumors (hazard ratio $(\mathrm{HR})=2.252 ; P=0.034$ ) and progression of muscle-invasive bladder tumors ( $\mathrm{HR}=3.690$; $P=0.077)$. However, the levels of GR expression were not significantly associated with the prognosis of the patients with UUT tumor in our study [46].

\section{Progestogens and PR}

A case-control study demonstrated significant decreases in bladder cancer incidence in multiparous women or women with oral contraceptive use [63]. In a study using a transgenic model for bladder cancer, multiparous female mice developed significantly smaller tumors than nulliparous females [64]. These observations imply benefits of not only estrogens but also progestogens for preventing the development of urothelial tumors.

Hormone-binding assay showed that 1 of 3 noninvasive and 3 of 3 advanced urothelial tumors were positive for PR [65]. An immunohistochemical study also demonstrated PR expression in the urothelium in 18 of 20 bladders from male children aged 1-12 [66]. Nonetheless, two subsequent immunohistochemical studies in 198 [53] and 410 [54] bladder cancer specimens failed to detect PR signals (Table 1). In another study of bladder tumors, the positive rates of PR were $2 \%$ and $4 \%$ in nonneoplastic urothelium and carcinoma tissues, respectively [43]. We recently showed that $13 \%$ of nonneoplastic urothelial tissues from the UUT and $16 \%$ of UUT tumors were immunoreactive for PR [46]. There was no significant difference in PR expression between low-grade versus high-grade or non-muscle-invasive versus muscleinvasive UUT tumors. Interestingly, in our study, PR positivity in pT3 or pT4 UUT tumors was strongly associated with disease-specific mortality.

\section{Vitamin D and VDR}

Low serum levels of vitamin $\mathrm{D}$ have been implicated in the risk of bladder cancer [67]. VDR gene polymorphism resulting in reduction of receptor activity has also been correlated with higher incidence of bladder cancer [68]. Furthermore, vitamin $\mathrm{D}$ was shown to prevent bladder tumorigenesis in rats treated with a carcinogen $\mathrm{N}$-methylnitrosourea as well as to inhibit cell growth of VDR-positive bladder cancer lines [69]. Thus, VDR signals appear to play a protective role in bladder tumor outgrowth.

VDR was found positive immunohistochemically in 86$100 \%$ of bladder tumors $[70,71]$ (Table 1 ). In contrast to the above findings, however, upregulation of VDR expression was seen in high-grade and muscle-invasive tumors, compared with low-grade and non-muscle-invasive tumors, respectively, in one of the studies [70]. Strong VDR expression was significantly associated with lower progression-free survival and cancer-specific survival rates.

\section{Retinoic Acids and Retinoid Receptors}

The preventive effects of retinoic acids, including vitamin A and its derivatives, on bladder cancer development have been assessed. A recent meta-analysis involving 25 studies demonstrated a significant inverse association between dietary intake of vitamin A/retinol and bladder cancer risk [72]. Preclinical studies also showed that retinoids inhibited bladder carcinogenesis in animals treated with BBN [73] and cell proliferation of bladder cancer lines [74].

In a study using a PCR-based method, all of the nonneoplastic bladders were found to express the retinoid receptors [75]. However, some of muscle-invasive bladder cancers lost $\operatorname{RAR} \alpha(60 \%), \operatorname{RAR} \gamma(20 \%)$, and $\operatorname{RXR} \alpha$ (40\%), while they were positive in all non-muscle-invasive tumors. RAR $\beta 2$ was positive in $50 \%$ of non-muscle-invasive tumors and $40 \%$ of muscle-invasive tumors. In addition, methylated $\operatorname{RAR} \beta$ was frequently found in bladder cancer tissues and urine samples from bladder cancer patients [76-78], suggesting its utility as a urine marker. Specifically, the sensitivity of RAR $\beta$ for tumor detection was higher than that of urine cytology (68\% versus $46 \%$ for all cases; $67 \%$ versus $11 \%$ for grade 1 tumors) [77].

\section{PPARs}

There has been a link between the use of pioglitazone, a PPAR agonist prescribed as a hypoglycemic drug, and bladder cancer risk [79]. Indeed, treatment with a $\operatorname{PPAR} \gamma$ agonist rosiglitazone or PPAR $\gamma$ overexpression resulted in significant increases in bladder cancer cell migration and invasion [80]. Earlier studies conversely showed that PPAR $\gamma$ agonists inhibited bladder cancer cell growth $[81,82]$. Of note, there appear to be multiple mechanisms for inducing antitumor effects of PPAR $\gamma$ agonists, some of which are independent of PPAR $\gamma$ signals [83]. Additionally, in situ hybridization showed that $P P A R \gamma$ gene was often amplified in bladder cancer specimens $[80,81]$.

\section{Orphan Nuclear Receptors}

Okegawa et al. recently demonstrated up- or downregulation of a variety of orphan nuclear receptor genes in bladder cancer tissues, compared with paired normal bladders [84]. Of these receptors, hepatocyte nuclear factor $4 \gamma$ (HNF4G) was most frequently elevated in tumors and its overexpression 
TABLE 2: Molecules regulated by sex hormone receptor signaling in urothelial carcinoma.

\begin{tabular}{|c|c|c|c|c|}
\hline & Associated receptor signaling & $\begin{array}{l}\text { Effect on urothelial carcinogenesis and/or } \\
\text { cancer progression }\end{array}$ & Hormone effect & Reference \\
\hline CD24 & AR & Stimulation & Upregulation & {$[88]$} \\
\hline$\beta$-catenin & $\mathrm{AR}$ & Stimulation & Upregulation & {$[92,93]$} \\
\hline Slug & $\mathrm{AR}$ & Stimulation & Upregulation & {$[42]$} \\
\hline EGFR & $\mathrm{AR}$ & Stimulation & Upregulation & {$[31]$} \\
\hline ERBB2 & $\mathrm{AR}$ & Stimulation & Upregulation & {$[31]$} \\
\hline Akt & $\mathrm{AR} / \mathrm{ER} \alpha$ & Stimulation & Upregulation/downregulation & {$[31,51]$} \\
\hline ERK1/2 & $\mathrm{AR}$ & Stimulation & Upregulation & {$[31]$} \\
\hline Cyclin D1 & $\mathrm{AR}$ & Stimulation & Upregulation & [26] \\
\hline Cyclin D3 & $\mathrm{AR}$ & Stimulation & Upregulation & [29] \\
\hline Cyclin E & $\mathrm{AR}$ & Stimulation & Upregulation & [29] \\
\hline FGFR3 & $\mathrm{AR}$ & Stimulation & Upregulation & [29] \\
\hline UGT1A & $\mathrm{AR} / \mathrm{ER} \beta$ & Inhibition & Downregulation/upregulation (SVHUC) & {$[28,110]$} \\
\hline p53 & AR & Inhibition & Downregulation & {$[29,118]$} \\
\hline $\mathrm{p} 21$ & $\mathrm{AR}$ & Inhibition & Downregulation & {$[29,118]$} \\
\hline PTEN & $\mathrm{AR}$ & Inhibition & Downregulation & [29] \\
\hline c-myc & $\mathrm{AR}$ & Stimulation & Upregulation & [29] \\
\hline Bcl-xL & $\mathrm{AR}$ & Stimulation & Upregulation & [26] \\
\hline MMP-9 & $\mathrm{AR}$ & Stimulation & Upregulation & {$[26]$} \\
\hline ELK1 & $\mathrm{AR}$ & Stimulation & Up-regulation & {$[33]$} \\
\hline GATA3 & $\mathrm{AR} / \mathrm{ER} \beta$ & Inhibition & Downregulation/upregulation (SVHUC) & {$[29]$} \\
\hline INPP4B & $\mathrm{ER} \alpha$ & Inhibition & Upregulation & {$[51]$} \\
\hline
\end{tabular}

AR: androgen receptor; ER: estrogen receptor.

promoted tumor growth in both in vitro and in vivo [84]. Nurrl was also often overexpressed in bladder cancers [84, 85], which correlated with the promotion of bladder cancer cell migration [85]. Immunohistochemistry of Nurrl in bladder cancer specimens showed significant increases in its expression levels in higher grade/stage tumors [85] (Table 1). Moreover, high cytoplasmic Nurrl expression, but not total expression, was an independent prognosticator of cancerspecific mortality $(\mathrm{HR}=4.894 ; P<0.001)$ [85]. Similarly, Nur77 was overexpressed especially in muscle-invasive bladder cancers $[84,86]$. However, Nur77 activation correlated with retardation of bladder tumor growth in cell line and animal models $[86,87]$.

\section{Molecules Regulated by Steroid Hormone Receptor Signaling}

Increasing evidence suggests the involvement of upstream pathways as well as downstream targets of steroid hormone receptor-mediated signals in the development and progression of urothelial cancer. Table 2 summarizes such molecules directly or indirectly regulated by AR and/or ER signals. The following are key molecules that androgens/estrogens have been shown to up- or downregulate via the AR/ER pathways in bladder cancer cells.

10.1. CD24. AR signals activate CD24, a glycoprotein and a cell adhesion molecule, in bladder cancer cells [88]. In animal models, CD24 overexpression and knockdown resulted in stimulation and inhibition, respectively, of the development of primary bladder cancer and its metastasis [88, 89]. Immunohistochemical analyses in bladder cancer specimens [89-91] have revealed that CD24 is expressed exclusively in tumor cells, but not in surrounding stromal cells. These studies also showed higher levels of CD24 expression in grade $2-3$ tumors $(74 \%)$ than in grade 1 tumors $(28 \% ; P<0.001)$ [90], in $\geq$ pT3 tumors than in $\leq$ pT2 tumors $(P=0.036)$ [91], or in metastatic tumors (93\%) than in primary tumors $(75 \%$; $P=0.006$ ) [89]. Furthermore, elevated CD24 expression was associated with recurrence of non-muscle-invasive tumors $(P<0.001$ for all cases or grades $2-3 ; P=0.042$ for grade 1) [90] or cancer-specific mortality in patients with muscle-invasive tumor $(P<0.001)$ [91] in univariate settings. However, CD24 was not an independent prognosticator for muscle-invasive bladder cancers ( $\mathrm{HR}=1.12 ; P=0.84)$ [91].

10.2. $\beta$-Catenin. AR signals activate $\mathrm{Wnt} / \beta$-catenin signaling in bladder cancer cells $[92,93] . \beta$-Catenin, as a key component of the Wnt signaling pathway, is a multifunctional protein and is known to activate target genes, such as the protooncogene $c-m y c$, the cell cycle activator $c y c l i n D 1$, and the epidermal growth factor receptor (EGFR). Using an animal model for bladder cancer, $\beta$-catenin was shown to induce tumorigenesis, and androgen-mediated AR signals appeared to synergize with $\beta$-catenin [93]. There are conflicting data as to the correlation of $\beta$-catenin staining in bladder cancer 
specimens with tumor aggressiveness. Consistent with the findings in other studies [94, 95], we observed downregulation of membranous $\beta$-catenin expression in bladder cancer, compared with nonneoplastic urothelium [92]. In addition, loss or reduced expression of membranous $\beta$-catenin, as well as nuclear accumulation of $\beta$-catenin as a hallmark of Wnt $\beta$ catenin activation, correlated with higher tumor grade, more advanced tumor stage, and/or worse patient outcomes [42, 92, $94,96]$. Coexpression of nuclear $\beta$-catenin and AR in bladder cancer cells was also noted $[42,92]$.

10.3. Slug. Androgens were shown to upregulate Slug expression in bladder cancer cells, which could subsequently induce epithelial-to-mesenchymal transition through the activation of Wnt/ $\beta$-catenin signaling [42]. Slug expression was significantly upregulated in high-stage bladder cancers (e.g., nonmuscle-invasive $27 \%$ versus muscle-invasive $77 \%, P=0.023$ [42]; lymph node-negative $58 \%$ versus lymph node-positive $89 \%, P=0.012$ [97]; non-muscle-invasive 23\% versus muscle-invasive $77 \%, P=0.04$ [98]), whereas there were no statistically significant differences in Slug expression between low-grade and high-grade tumors in these 3 studies. Prognostic significance of Slug expression in bladder tumors was not seen or was not assessed in these studies.

10.4. EGFR/ERBB2. Activation of the EGFR family, such as EGFR and ERBB2, is known to involve bladder tumorigenesis and cancer progression. Accordingly, the efficacy of targeted therapy directed at EGFR signals has been assessed in bladder cancer [99-104]. We demonstrated that androgen upregulated the expression of EGFR and ERBB2 as well as the levels of phosphorylation of their downstream proteins AKT and extracellular signal-regulated kinase- (ERK-) 1/2 via the AR pathway in bladder cancer cells [31]. EGF could also induce bladder cancer cell proliferation via modulating AR signals [32]. Alterations of the EGFR family, such as protein overexpression and gene amplification or mutation, have been extensively studied in bladder cancer specimens, providing mixed results regarding their prognostic values [104-109]. For instance, some studies suggested that ERBB2 overexpression was a poor prognostic factor, while others did not. Nonetheless, ERBB2 was found to be overexpressed in muscle-invasive bladder cancers in most of the studies.

10.5. UGT1A. UGT1A, a major phase II drug metabolism enzyme, plays a critical role in detoxifying bladder carcinogens. In a normal urothelial cell line SVHUC as well as in normal mouse bladders, androgens/estrogens decreased/increased the expression levels of UGT1A and its subtypes via the $\mathrm{AR} / \mathrm{ER} \beta$ pathways, respectively $[28,110]$. An initial immunohistochemical study showed that 6 of 19 bladder tumors lost UGT1A, while benign tissues consistently expressed it [111]. Our immunohistochemical staining subsequently showed reduced expression of UGT1A in 145 urothelial neoplasms, compared with paired nonneoplastic urothelial tissues, as well as inverse correlations between UGT1A levels and tumor grade or pT stage [110]. Decreased UGT1A expression was also strongly associated with the progression of high-grade non-muscle-invasive tumors $(P=0.038)$ or worse cancer-specific survival in patients with muscleinvasive tumor $(P=0.016)$, and the latter was an independent prognosticator $(\mathrm{HR}=3.413 ; P=0.010)$ [110]. In addition, the expression of UGT1A was positively and negatively correlated with the levels of $\operatorname{ER} \alpha$ and $\operatorname{ER} \beta$, respectively.

10.6. ELK1. ELK1, a member of the ETS-domain family of transcription factors, is known to involve cell proliferation, cell cycle control, and apoptosis via regulating the expression of a variety of genes, including $c$-fos protooncogene. We recently demonstrated that androgens activated ELK1 in bladder cancer cells and promoted the proliferation of only ELK1-positive cells and the migration/invasion of both ELK1positive and ELK1-negative cells [33]. Androgens also failed to significantly induce AR transcriptional activity in ELK1 knockdown bladder cancer cells. Our immunohistochemical staining showed significant increases in the expression of ELK1 and phospho-ELK1 (an activated form of ELK1) in bladder tumors, compared with nonneoplastic urothelial tissues [33]. The expression of ELK1/phospho-ELK1 versus AR was significantly correlated. While there were no significant correlations between the levels of ELK1 or phospho-ELK1 and tumor grades or stages, phospho-ELK1 positivity precisely predicted the recurrence of non-muscle-invasive tumors in a univariate setting $(P=0.043)$ as well as a worse outcome of muscle-invasive tumors in both univariate $(P=0.045$ for disease progression; $P=0.008$ for cancer-specific mortality) and multivariate $(\mathrm{HR}=2.693 ; P=0.021$ for cancer-specific mortality) settings. Subsequent immunohistochemistry in bladder cancer specimens from patients who received neoadjuvant chemotherapy revealed that phospho-ELK1 positivity strongly correlated with chemoresistance [112]. Indeed, ELK1 inactivation resulted in enhancement of the cytotoxic activity of cisplatin in bladder cancer cells [112].

10.7. GATA3. GATA3, a member of the GATA family of zincfinger transcription factors, has recently been recognized as a urothelial marker and its immunohistochemistry has therefore been widely used in diagnostic surgical pathology [113-115]. Using SVHUC cells with carcinogen challenge, we demonstrated that GATA3 strongly prevented neoplastic transformation of urothelial cells [29]. GATA3 knockdown in SVHUC exposed to the chemical carcinogen resulted in downregulation of the molecules that play a protective role in bladder tumorigenesis, such as UGT1A, PTEN, p53, and p21, and upregulation of oncogenic genes, such as c-myc, cyclins D1/D3/E, and FGFR3. Additionally, similar to the findings in UGT1A described above, androgens/estrogens down/ upregulated GATA3 expression in nonneoplastic urothelial cells via the AR/ER $\beta$ pathways, respectively [29]. GATA3 knockdown in bladder cancer lines also resulted in promotion of cell invasion and migration as well as induction of the expression of their related molecules, such as MMP2 and MMP-9 [116], while androgens did not significantly change the levels of GATA3 expression in these cells [29]. Our immunohistochemical data showed that GATA3 was positive in $98 \%$ of nonneoplastic urothelial tissues versus $86 \%$ of urothelial neoplasms as well as in $98 \%$ of low-grade and/or non-muscle-invasive tumors versus $72-80 \%$ of high-grade 
and/or muscle-invasive tumors [117]. In tumors, there were strong correlations between GATA3 expression versus AR overexpression, ER $\alpha$ overexpression, or loss of ER $\beta$ expression. We also demonstrated that patients with GATA3positive muscle-invasive tumor had a significantly higher risk of disease progression in a univariate setting $(P=0.048)$ and, in this subgroup, strong GATA3 expression was correlated with tumor progression ( $\mathrm{HR}=2.435 ; P=0.052)$ or cancerspecific survival $(\mathrm{HR}=3.673 ; P=0.040)$ in a multivariate setting [117].

10.8. Inositol Polyphosphate 4-Phosphatase Type II (INPP4B). INPP4B has been recognized as a tumor suppressor of several types of malignancies, such as breast and prostate cancers, but its role in bladder cancer remained unclear. In bladder cancer cells, estrogens were shown to upregulate INPP4B via the ER $\alpha$ pathway, resulting in inhibition of AKT activity and cell growth [51]. Chromatin immunoprecipitation assay further revealed that $\mathrm{ER} \alpha$ could bind to a putative estrogen response element region of the INPP4B promoter in bladder cancer cells. Immunohistochemistry showed that INPP4B was positive in $62 \%$ of bladder tumors, which was significantly lower than in benign urothelial tissues $(87 \% ; P<$ 0.001 ) [51]. Similarly, $75 \%$ of low-grade versus $53 \%$ of highgrade tumors $(P=0.016)$ as well as $74 \%$ of non-muscleinvasive versus $44 \%$ of muscle-invasive tumors $(P<0.001)$ were INPP4B-positive. There was also a positive correlation between INPP4B expression and ER $\alpha$ expression. However, no prognostic significance of INPP4B expression in bladder tumors has been demonstrated.

\section{Conclusion}

Mounting evidence suggests that steroid hormone receptormediated signals play a critical role in urothelial tumorigenesis and cancer progression. Various molecules, as downstream targets, have also been shown to be modulated by these signals. Immunohistochemical studies in surgical specimens have identified significant differences in the expression levels of several steroid hormone receptors and their related proteins between nonneoplastic urothelium versus urothelial tumor and between low-grade/non-muscle-invasive versus high-grade/muscle-invasive urothelial tumors. More importantly, although the underlying mechanisms of how steroid hormone receptors and related signals regulate urothelial tumor outgrowth remain far from being fully understood, the available data support that these can serve as biomarkers of urothelial tumors, especially their prognosticators. Further investigation of steroid hormone receptors as well as other molecules directly or indirectly regulated by steroid hormones may help develop not only better strategies for the management of urothelial tumors but also more reliable biomarkers.

\section{Conflict of Interests}

The authors declare that they have no conflict of interests.

\section{References}

[1] L. A. Torre, F. Bray, R. L. Siegel, J. Ferlay, J. Lortet-Tieulent, and A. Jemal, "Global cancer statistics, 2012," CA-A Cancer Journal for Clinicians, vol. 65, no. 2, pp. 87-108, 2015.

[2] C. Zheng, Y. Lv, Q. Zhong, R. Wang, and Q. Jiang, "Narrow band imaging diagnosis of bladder cancer: systematic review and meta-analysis," BJU International, vol. 110, no. 11, pp. E680E687, 2012.

[3] M. Helenius, E. Brekkan, P. Dahlman, M. Lönnemark, and A. Magnusson, "Bladder cancer detection in patients with gross haematuria: computed tomography urography with enhancement-triggered scan versus flexible cystoscopy," Scandinavian Journal of Urology, vol. 49, no. 5, pp. 377-381, 2015.

[4] K. E. van Kessel, L. van Neste, I. Lurkin, E. C. Zwarthoff, and W. van Criekinge, "Evaluation of an epigenetic profile for the detection of bladder cancer in hematuria patients," The Journal of Urology, 2015.

[5] M.-P. Raitanen, R. Aine, E. Rintala et al., "Differences between local and review urinary cytology in diagnosis of bladder cancer. An interobserver multicenter analysis," European Urology, vol. 41, no. 3, pp. 284-289, 2002.

[6] Y. Lotan and C. G. Roehrborn, "Sensitivity and specificity of commonly available bladder tumor markers versus cytology: results of a comprehensive literature review and meta-analyses," Urology, vol. 61, no. 1, pp. 109-118, 2003.

[7] B. W. G. van Rhijn, H. G. van der Poel, and T. H. van der Kwast, "Urine markers for bladder cancer surveillance: a systematic review," European Urology, vol. 47, no. 6, pp. 736-748, 2005.

[8] G. Mowatt, S. Zhu, M. Kilonzo et al., "Systematic review of the clinical effectiveness and cost-effectiveness of photodynamic diagnosis and urine biomarkers (FISH, ImmunoCyt, NMP22) and cytology for the detection and follow-up of bladder cancer," Health Technology Assessment, vol. 14, no. 4, pp. 1-331, 2010.

[9] A. M. Kamat, A. Vlahou, J. A. Taylor et al., "Considerations on the use of urine markers in the management of patients with high-grade non-muscle-invasive bladder cancer," Urologic Oncology, vol. 32, no. 7, pp. 1069-1077, 2014.

[10] E. Scosyrev, D. Trivedi, and E. Messing, "Female bladder cancer: incidence, treatment, and outcome," Current Opinion in Urology, vol. 20, no. 5, pp. 404-408, 2010.

[11] H. Fajkovic, J. A. Halpern, E. K. Cha et al., "Impact of gender on bladder cancer incidence, staging, and prognosis," World Journal of Urology, vol. 29, no. 4, pp. 457-463, 2011.

[12] L. A. Kluth, H. Fajkovic, E. Xylinas et al., "Female gender is associated with higher risk of disease recurrence in patients with primary T1 high-grade urothelial carcinoma of the bladder," World Journal of Urology, vol. 31, no. 5, pp. 1029-1036, 2013.

[13] I. Lucca, H. Fajkovic, and T. Klatte, "Sex steroids and gender differences in nonmuscle invasive bladder cancer," Current Opinion in Urology, vol. 24, no. 5, pp. 500-505, 2014.

[14] M. Schmid, S. F. Shariat, A. Soave, O. Engel, M. Fisch, and M. Rink, "Contemporary gender-specific outcomes in Germany after radical cystectomy for bladder cancer," Current Urology Reports, vol. 15, no. 6, article 409, 2014.

[15] R. L. Siegel, K. D. Miller, and A. Jemal, “Cancer statistics, 2015," CA Cancer Journal for Clinicians, vol. 65, no. 1, pp. 5-29, 2015.

[16] H. Miyamoto, Y. Zheng, and K. Izumi, "Nuclear hormone receptor signals as new therapeutic targets for urothelial carcinoma," Current Cancer Drug Targets, vol. 12, no. 1, pp. 14-22, 2012. 
[17] Y. Li, K. Izumi, and H. Miyamoto, "The role of the androgen receptor in the development and progression of bladder cancer," Japanese Journal of Clinical Oncology, vol. 42, no. 7, Article ID hys072, pp. 569-577, 2012.

[18] I. Hsu, S. Vitkus, J. Da, and S. Yeh, "Role of oestrogen receptors in bladder cancer development," Nature Reviews Urology, vol. 10, no. 6, pp. 317-326, 2013.

[19] E. Okajima, T. Hiramatsu, K. Iriya, M. Ijuin, S. Matsushima, and K. Yamada, "Effect of sex hormones on development of urinary bladder tumours in rats induced by N-butyl-N-(4hydroxybutyl) nitrosamine," Urological Research, vol. 3, no. 2, pp. 73-79, 1975.

[20] L. M. Reid, I. Leav, and P. W. L. Kwan, "Characterization of a human, sex steroid-responsive transitional cell carcinoma maintained as a tumor line (R198) in athymic nude mice," Cancer Research, vol. 44, no. 10, pp. 4560-4573, 1984.

[21] S. Imada, H. Akaza, Y. Ami, K. Koiso, Y. Ideyama, and T. Takenaka, "Promoting effects and mechanisms of action of androgen in bladder carcinogenesis in male rats," European Urology, vol. 31, no. 3, pp. 360-364, 1997.

[22] S. Saikawa, H. Kanamaru, S. Noriki, S. Matsukawa, and K. Okada, "The effects of organ resection on rat urinary bladder carcinogenesis," Urological Research, vol. 29, no. 3, pp. 210-215, 2001.

[23] H. Miyamoto, Z. Yang, Y.-T. Chen et al., "Promotion of bladder cancer development and progression by androgen receptor signals," Journal of the National Cancer Institute, vol. 99, no. 7, pp. 558-568, 2007.

[24] A. M. Johnson, M. J. O’Connell, H. Miyamoto et al., "Androgenic dependence of exophytic tumor growth in a transgenic mouse model of bladder cancer: a role for thrombospondin-1," BMC Urology, vol. 8, no. 1, article 7, 2008.

[25] S. A. Boorjian, H. V. Heemers, I. Frank et al., "Expression and significance of androgen receptor coactivators in urothelial carcinoma of the bladder," Endocrine-Related Cancer, vol. 16, no. 1, pp. 123-137, 2009.

[26] J.-T. Wu, B.-M. Han, S.-Q. Yu, H.-P. Wang, and S.-J. Xia, "Androgen receptor is a potential therapeutic target for bladder cancer," Urology, vol. 75, no. 4, pp. 820-827, 2010.

[27] S. Imaoka, Y. Yoneda, T. Sugimoto et al., "Androgen regulation of CYP4B1 responsible for mutagenic activation of bladder carcinogens in the rat bladder: detection of CYP4B1 mRNA by competitive reverse transcription-polymerase chain reaction," Cancer Letters, vol. 166, no. 2, pp. 119-123, 2001.

[28] K. Izumi, Y. Zheng, J.-W. Hsu, C. Chang, and H. Miyamoto, "Androgen receptor signals regulate UDP-glucuronosyltransferases in the urinary bladder: a potential mechanism of androgen-induced bladder carcinogenesis," Molecular Carcinogenesis, vol. 52, no. 2, pp. 94-102, 2013.

[29] Y. Li, H. Ishiguro, T. Kawahara, Y. Miyamoto, K. Izumi, and H. Miyamoto, "GATA3 in the urinary bladder: suppression of neoplastic transformation and down-regulation by androgens," American Journal of Cancer Research, vol. 4, no. 5, pp. 461-473, 2014.

[30] C. Tuygun, D. Kankaya, A. Imamoglu et al., "Sex-specific hormone receptors in urothelial carcinomas of the human urinary bladder: a comparative analysis of clinicopathological features and survival outcomes according to receptor expression," Urologic Oncology, vol. 29, no. 1, pp. 43-51, 2011.

[31] Y. Zheng, K. Izumi, J. L. Yao, and H. Miyamoto, "Dihydrotestosterone upregulates the expression of epidermal growth factor receptor and ERBB2 in androgen receptor-positive bladder cancer cells," Endocrine-Related Cancer, vol. 18, no. 4, pp. 451464, 2011.

[32] K. Izumi, Y. Zheng, Y. Li, J. Zaengle, and H. Miyamoto, "Epidermal growth factor induces bladder cancer cell proliferation through activation of the androgen receptor," International Journal of Oncology, vol. 41, no. 5, pp. 1587-1592, 2012.

[33] T. Kawahara, H. K. Shareef, A. K. Aljarah et al., "ELK1 is upregulated by androgen in bladder cancer cells and promotes tumor progression," Oncotarget, vol. 6, no. 30, pp. 29860-29876, 2015.

[34] M. Shiota, A. Yokomizo, A. Takeuchi et al., "Secondary bladder cancer after anticancer therapy for prostate cancer: reduced comorbidity after androgen-deprivation therapy," Oncotarget, vol. 6, no. 16, pp. 14710-14719, 2015.

[35] K. Izumi, M. Taguri, H. Miyamoto et al., "Androgen deprivation therapy prevents bladder cancer recurrence," Oncotarget, vol. 5, no. 24, pp. 12665-12674, 2014.

[36] S. Boorjian, S. Ugras, N. P. Mongan et al., "Androgen receptor expression is inversely correlated with pathologic tumor stage in bladder cancer," Urology, vol. 64, no. 2, pp. 383-388, 2004.

[37] E. C. Kauffman, B. D. Robinson, M. J. Downes et al., "Role of androgen receptor and associated lysine-demethylase coregulators, LSD1 and JMJD2A, in localized and advanced human bladder cancer," Molecular Carcinogenesis, vol. 50, no. 12, pp. 931-944, 2011.

[38] C. Mir, S. F. Shariat, T. H. van der Kwast et al., "Loss of androgen receptor expression is not associated with pathological stage, grade, gender or outcome in bladder cancer: a large multiinstitutional study," BJU International, vol. 108, no. 1, pp. 24-30, 2011.

[39] K.-M. Rau, Y.-J. Chen, M.-T. Sun, and H.-Y. Kang, "Prognostic effects and regulation of activin $\mathrm{A}$, maspin, and the androgen receptor in upper urinary tract urothelial carcinoma," Anticancer Research, vol. 31, no. 5, pp. 1713-1720, 2011.

[40] H. Miyamoto, J. L. Yao, A. Chaux et al., "Expression of androgen and oestrogen receptors and its prognostic significance in urothelial neoplasm of the urinary bladder," BJU International, vol. 109, no. 11, pp. 1716-1726, 2012.

[41] C.-R. Shyr, C.-C. Chen, T.-F. Hsieh et al., "The expression and actions of androgen receptor in upper urinary tract urothelial carcinoma (UUTUC) tissues and the primary cultured cells," Endocrine, vol. 43, no. 1, pp. 191-199, 2013.

[42] Y. Jing, D. Cui, W. Guo et al., "Activated androgen receptor promotes bladder cancer metastasis via Slug mediated epithelialmesenchymal transition," Cancer Letters, vol. 348, no. 1-2, pp. 135-145, 2014.

[43] R. Mashhadi, G. Pourmand, F. Kosari et al., "Role of steroid hormone receptors in formation and progression of bladder carcinoma: a case-control study," Urology Journal, vol. 11, no. 6, pp. 1968-1973, 2014.

[44] J. K. Nam, S. W. Park, S. D. Lee, and M. K. Chung, "Prognostic value of sex-hormone receptor expression in non-muscleinvasive bladder cancer," Yonsei Medical Journal, vol. 55, no. 5, pp. 1214-1221, 2014.

[45] E. M. Williams, J. P. Higgins, A. R. Sangoi, J. K. McKenney, and M. L. Troxell, "Androgen receptor immunohistochemistry in genitourinary neoplasms," International Urology and Nephrology, vol. 47, no. 1, pp. 81-85, 2015.

[46] E. Kashiwagi, K. Fujita, S. Yamaguchi et al., "Expression of steroid hormone receptors and its prognostic significance in 
urothelial carcinoma of the upper urinary tract (UCUUT)," The Journal of Urology, vol. 193, no. 4, supplement, article e69, 2015.

[47] H. T. Kim, B. C. Kim, I. Y. Kim et al., "Raloxifene, a mixed estrogen agonist/antagonist, induces apoptosis through cleavage of BAD in TSU-PR1 human cancer cells," The Journal of Biological Chemistry, vol. 277, no. 36, pp. 32510-32515, 2002.

[48] M. P. Waalkes, J. Liu, J. M. Ward, D. A. Powell, and B. A. Diwan, "Urogenital carcinogenesis in female CD1 mice induced by in utero arsenic exposure is exacerbated by postnatal diethylstilbestrol treatment," Cancer Research, vol. 66, no. 3, pp. 13371345, 2006.

[49] G. Sonpavde, N. Okuno, H. Weiss et al., "Efficacy of selective estrogen receptor modulators in nude mice bearing human transitional cell carcinoma," Urology, vol. 69, no. 6, pp. 12211226, 2007.

[50] J. Teng, Z.-Y. Wang, D. F. Jarrard, and D. E. Bjorling, "Roles of estrogen receptor alpha and beta in modulating urothelial cell proliferation," Endocrine-Related Cancer, vol. 15, no. 1, pp. 351364, 2008.

[51] I. Hsu, C.-R. Yeh, S. Slavin et al., "Estrogen receptor alpha prevents bladder cancer via INPP4B inhibited akt pathway in vitro and in vivo," Oncotarget, vol. 5, no. 17, pp. 7917-7935, 2014.

[52] S. S. Shen, C. L. Smith, J.-T. Hsieh et al., "Expression of estrogen receptors- $\alpha$ and $-\beta$ in bladder cancer cell lines and human bladder tumor tissue," Cancer, vol. 106, no. 12, pp. 2610-2616, 2006.

[53] C. Bolenz, Y. Lotan, R. Ashfaq, and S. F. Shariat, "Estrogen and progesterone hormonal receptor expression in urothelial carcinoma of the bladder," European Urology, vol. 56, no. 6, pp. 1093 1095, 2009.

[54] W. Tan, S. Boorjian, P. Advani et al., "The estrogen pathway: estrogen receptor- $\alpha$, progesterone receptor, and estrogen receptor- $\beta$ expression in radical cystectomy urothelial cell carcinoma specimens," Clinical Genitourinary Cancer, vol. 13, no. 5, pp. 476-484, 2015.

[55] P. R. Croft, S. L. Lathrop, R. M. Feddersen, and N. E. Joste, "Estrogen receptor expression in papillary urothelial carcinoma of the bladder and ovarian transitional cell carcinoma," Archives of Pathology and Laboratory Medicine, vol. 129, no. 2, pp. 194199, 2005.

[56] S. Kontos, A. Kominea, M. Melachrinou, E. Balampani, and G. Sotiropoulou-Bonikou, "Inverse expression of estrogen receptor- $\beta$ and nuclear factor- $\kappa \mathrm{B}$ in urinary bladder carcinogenesis," International Journal of Urology, vol. 17, no. 9, pp. 801-809, 2010.

[57] E. C. Kauffman, B. D. Robinson, M. Downes et al., "Estrogen receptor- $\beta$ expression and pharmacological targeting in bladder cancer," Oncology Reports, vol. 30, no. 1, pp. 131-138, 2013.

[58] K. Dietrich, A. Schned, J. Fortuny et al., "Glucocorticoid therapy and risk of bladder cancer," British Journal of Cancer, vol. 101, no. 8, pp. 1316-1320, 2009.

[59] Y. Zheng, K. Izumi, Y. Li, H. Ishiguro, and H. Miyamoto, "Contrary regulation of bladder cancer cell proliferation and invasion by dexamethasone-mediated glucocorticoid receptor signals," Molecular Cancer Therapeutics, vol. 11, no. 12, pp. 2621-2632, 2012.

[60] H. Ishiguro, T. Kawahara, Y. Zheng, E. Kashiwagi, Y. Li, and H. Miyamoto, "Differential regulation of bladder cancer growth by various glucocorticoids: Corticosterone and prednisone inhibit cell invasion without promoting cell proliferation or reducing cisplatin cytotoxicity," Cancer Chemotherapy and Pharmacology, vol. 74, no. 2, pp. 249-255, 2014.
[61] Y. Zheng, H. Ishiguro, H. Ide et al., "Compound A inhibits bladder cancer growth predominantly via glucocorticoid receptor transrepression," Molecular Endocrinology, vol. 29, no. 10, pp. 1486-1497, 2015.

[62] H. Ishiguro, T. Kawahara, Y. Zheng, G. J. Netto, and H. Miyamoto, "Reduced glucocorticoid receptor expression predicts bladder tumor recurrence and progression," American Journal of Clinical Pathology, vol. 142, no. 2, pp. 157-164, 2014.

[63] B. J. Wolpert, S. Amr, S. Ezzat et al., "Estrogen exposure and bladder cancer risk in Egyptian women," Maturitas, vol. 67, no. 4, pp. 353-357, 2010.

[64] A. M. Johnson, M. J. O’Connell, E. M. Messing, and J. E. Reeder, "Decreased bladder cancer growth in parous mice," Urology, vol. 72, no. 3, pp. 470-473, 2008.

[65] R. F. X. Noronha and B. R. Rao, "Sex hormone receptors in localized and advanced transitional cell carcinoma of urinary tract in humans," Urology, vol. 28, no. 5, pp. 401-403, 1986.

[66] S. Celayir, Z. Ilçe, and S. Dervisoglu, "The sex hormone receptors in the bladder in childhood-I: preliminary report in male subjects," European Journal of Pediatric Surgery, vol. 12, no. 5, pp. 312-317, 2002.

[67] Y. Liao, J.-L. Huang, M. X. Qiu, and Z. W. Ma, "Impact of serum vitamin D level on risk of bladder cancer: a systemic review and meta-analysis," Tumor Biology, vol. 36, no. 3, pp. 1567-1572, 2015.

[68] R. D. Mittal, P. K. Manchanda, S. Bhat, and H. K. Bid, "Association of vitamin-D receptor (Fok-I) gene polymorphism with bladder cancer in an Indian population," BJU International, vol. 99, no. 4, pp. 933-937, 2007.

[69] B. R. Konety, J. P. Lavelle, G. Pirtskalaishvili et al., "Effects of vitamin $\mathrm{D}$ (calcitriol) on transitional cell carcinoma of the bladder in vitro and in vivo," The Journal of Urology, vol. 165, no. 1, pp. 253-258, 2001.

[70] G. G. Hermann and C. B. Andersen, "Transitional cell carcinoma express vitamin D receptors," Scandinavian Journal of Urology and Nephrology, vol. 31, no. 2, pp. 161-166, 1997.

[71] M. O. Sahin, A. E. Canda, K. Yorukoglu, M. U. Mungan, M. Sade, and Z. Kirkali, "1,25 Dihydroxyvitamin $\mathrm{D}_{3}$ receptor expression in superficial transitional cell carcinoma of the bladder: a possible prognostic factor?" European Urology, vol. 47, no. 1, pp. 52-57, 2005.

[72] J.-E. Tang, R.-J. Wang, H. Zhong, B. Yu, and Y. Chen, "Vitamin A and risk of bladder cancer: a meta-analysis of epidemiological studies," World Journal of Surgical Oncology, vol. 12, article 130, 2014.

[73] P. J. Becci, H. J. Thompson, C. J. Grubbs et al., "Inhibitory effect of 13-cis-retinoic acid on urinary bladder carcinogenesis induced in C57BL/6 mice by $N$-butyl- $N$-(4-hydroxybutyl)nitrosamine," Cancer Research, vol. 38, no. 12, pp. 4463-4466, 1978.

[74] C. Zou, J. Zhou, L. Qian et al., "Comparing the effect of ATRA, 4-HPR, and CD437 in bladder cancer cells," Frontiers in Bioscience, vol. 11, no. 1, pp. 2007-2016, 2006.

[75] S. Boorjian, D. S. Scherr, N. P. Mongan, Y. Zhuang, D. M. Nanus, and L. J. Gudas, "Retinoid receptor mRNA expression profiles in human bladder cancer specimens," International Journal of Oncology, vol. 26, no. 4, pp. 1041-1048, 2005.

[76] R. Maruyama, S. Toyooka, K. O. Toyooka et al., "Aberrant promoter methylation profile of bladder cancer and its relationship to clinicopathological features," Cancer Research, vol. 61, no. 24, pp. 8659-8663, 2001. 
[77] M. W. Y. Chan, L. W. Chan, N. L. S. Tang et al., "Hypermethylation of multiple genes in tumor tissues and voided urine in urinary bladder cancer patients," Clinical Cancer Research, vol. 8, no. 2, pp. 464-470, 2002.

[78] L. Maldonado, M. Brait, C. Michailidi et al., "An epigenetic marker panel for recurrence risk prediction of low grade papillary urothelial cell carcinoma (LGPUCC) and its potential use for surveillance after transurethral resection using urine," Oncotarget, vol. 5, no. 14, pp. 5218-5233, 2014.

[79] D. Hillaire-Buys, J.-L. Faillie, and J.-L. Montastruc, "Pioglitazone and bladder cancer," The Lancet, vol. 378, no. 9802, pp. 1543-1544, 2011.

[80] D.-R. Yang, S.-J. Lin, X.-F. Ding et al., "Higher expression of peroxisome proliferator-activated receptor $\gamma$ or its activation by agonist thiazolidinedione-rosiglitazone promotes bladder cancer cell migration and invasion," Urology, vol. 81, no. 5, pp. 1109.e1-1109.e6, 2013.

[81] Y.-F. Guan, Y.-H. Zhang, R. M. Breyer, L. Davis, and M. D. Breyer, "Expression of peroxisome proliferator-activated receptor gamma (PPARgamma) in human transitional bladder cancer and its role in inducing cell death," Neoplasia, vol. 1, no. 4, pp. 330-339, 1999.

[82] W. Kassouf, S. Chintharlapalli, M. Abdelrahim, G. Nelkin, S. Safe, and A. M. Kamat, "Inhibition of bladder tumor growth by 1,1-bis( $3^{\prime}$-indolyl)-1-(p- substitutedphenyl)methanes: a new class of peroxisome proliferator-activated receptor $\gamma$ agonists," Cancer Research, vol. 66, no. 1, pp. 412-418, 2006.

[83] S. Wei, J. Yang, S.-L. Lee, S. K. Kulp, and C.-S. Chen, "PPAR $\gamma$ independent antitumor effects of thiazolidinediones," Cancer Letters, vol. 276, no. 2, pp. 119-124, 2009.

[84] T. Okegawa, K. Ushio, M. Imai, M. Morimoto, and T. Hara, "Orphan nuclear receptor HNF4G promotes bladder cancer growth and invasion through the regulation of the hyaluronan synthase 2 gene," Oncogenesis, vol. 2, article e58, 2013.

[85] T. Inamoto, B. A. Czerniak, C. P. Dinney, and A. M. Kamat, "Cytoplasmic mislocalization of the orphan nuclear receptor Nurrl is a prognostic factor in bladder cancer," Cancer, vol. 116, no. 2, pp. 340-346, 2010.

[86] S. D. Cho, S.-O. Lee, S. Chintharlapalli et al., "Activation of nerve growth factor-induced $\mathrm{B} \alpha$ by methylene-substituted diindolylmethanes in bladder cancer cells induces apoptosis and inhibits tumor growth," Molecular Pharmacology, vol. 77, no. 3, pp. 396-404, 2010.

[87] J. Wu, J. Liu, R. Jia, and H. Song, "Nur77 inhibits androgeninduced bladder cancer growth," Cancer Investigation, vol. 31, no. 10, pp. 654-660, 2013.

[88] J. B. Overdevest, K. H. Knubel, J. E. Duex et al., "CD24 expression is important in male urothelial tumorigenesis and metastasis in mice and is androgen regulated," Proceedings of the National Academy of Sciences of the United States of America, vol. 109, no. 51, pp. E3588-E3596, 2012.

[89] J. B. Overdevest, S. Thomas, G. Kristiansen, D. E. Hansel, S. C. Smith, and D. Theodorescu, "CD24 offers a therapeutic target for control of bladder cancer metastasis based on a requirement for lung colonization," Cancer Research, vol. 71, no. 11, pp. 38023811, 2011.

[90] T. Hofner, S. Macher-Goeppinger, C. Klein et al., "Expression and prognostic significance of cancer stem cell markers CD24 and CD44 in urothelial bladder cancer xenografts and patients undergoing radical cystectomy," Urologic Oncology: Seminars and Original Investigations, vol. 32, no. 5, pp. 678-686, 2014.
[91] C. Liu, S. Zheng, H. Shen et al., "Clinical significance of CD24 as a predictor of bladder cancer recurrence," Oncology Letters, vol. 6, no. 1, pp. 96-100, 2013.

[92] Y. Li, Y. Zheng, K. Izumi et al., "Androgen activates $\beta$-catenin signaling in bladder cancer cells," Endocrine-Related Cancer, vol. 20, no. 3, pp. 293-304, 2013.

[93] C. Lin, Y. Yin, K. Stemler et al., "Constitutive $\beta$-catenin activation induces male-specific tumorigenesis in the bladder urothelium," Cancer Research, vol. 73, no. 19, pp. 5914-5925, 2013.

[94] X. Garcia del Muro, A. Torregrosa, J. Muñoz et al., "Prognostic value of the expression of E-cadherin and $\beta$-catenin in bladder cancer," European Journal of Cancer, vol. 36, no. 3, pp. 357-362, 2000.

[95] X. Zhu, Y. Kanai, A. Saito, Y. Kondo, and S. Hirohashi, "Aberrant expression of $\beta$-catenin and mutation of exon 3 of the $\beta$ catenin gene in renal and urothelial carcinomas," Pathology International, vol. 50, no. 12, pp. 945-952, 2000.

[96] E. Kastritis, S. Murray, F. Kyriakou et al., "Somatic mutations of adenomatous polyposis coli gene and nuclear bcatenin accumulation have prognostic significance in invasive urothelial carcinomas: evidence for Wnt pathway implication," International Journal of Cancer, vol. 124, no. 1, pp. 103-108, 2009.

[97] Q. Yu, K. Zhang, X. Wang, X. Liu, and Z. Zhang, "Expression of transcription factors snail, slug, and twist in human bladder carcinoma," Journal of Experimental and Clinical Cancer Research, vol. 29, no. 1, article 119, 2010.

[98] K. Wu, J. Zeng, J. Zhou et al., "Slug contributes to cadherin switch and malignant progression in muscle-invasive bladder cancer development," Urologic Oncology: Seminars and Original Investigations, vol. 31, no. 8, pp. 1751-1760, 2013.

[99] R. S. Pruthi, M. Nielsen, S. Heathcote et al., "A phase II trial of neoadjuvant erlotinib in patients with muscle-invasive bladder cancer undergoing radical cystectomy: clinical and pathological results," BJU International, vol. 106, no. 3, pp. 349-354, 2010.

[100] C. Wülfing, J.-P. H. Machiels, D. J. Richel et al., "A single-arm, multicenter, open-label phase 2 study of lapatinib as the secondline treatment of patients with locally advanced or metastatic transitional cell carcinoma," Cancer, vol. 115, no. 13, pp. 28812890, 2009.

[101] D. P. Petrylak, C. M. Tangen, P. J. Van Veldhuizen Jr. et al., "Results of the Southwest Oncology Group phase II evaluation (study S0031) of ZD1839 for advanced transitional cell carcinoma of the urothelium," BJU International, vol. 105, no. 3, pp. 317-321, 2010.

[102] G. K. Philips, S. Halabi, B. L. Sanford, D. Bajorin, and E. J. Small, "A phase II trial of cisplatin $(C)$, gemcitabine $(G)$ and gefitinib for advanced urothelial tract carcinoma: results of Cancer and Leukemia Group B (CALGB) 90102," Annals of Oncology, vol. 20, no. 6, pp. 1074-1079, 2009.

[103] M. H. A. Hussain, G. R. MacVicar, D. P. Petrylak et al., "Trastuzumab, paclitaxel, carboplatin, and gemcitabine in advanced human epidermal growth factor receptor- $2 / \nu$-positive urothelial carcinoma: results of a multicenter phase II National Cancer Institute trial," Journal of Clinical Oncology, vol. 25, no. 16, pp. 2218-2224, 2007.

[104] B. A. Mooso, R. L. Vinall, M. Mudryj, S. A. Yap, R. W. deVere White, and P. M. Ghosh, "The role of EGFR family inhibitors in muscle invasive bladder cancer: a review of clinical data and molecular evidence," Journal of Urology, vol. 193, no. 1, pp. 19-29, 2015.

[105] C. B. Ching, M. B. Amin, R. R. Tubbs et al., "HER2 gene amplification occurs frequently in the micropapillary variant of 
urothelial carcinoma: Analysis by dual-color in situ hybridization," Modern Pathology, vol. 24, no. 8, pp. 1111-1119, 2011.

[106] M. de Martino, D. Zhuang, T. Klatte et al., "Impact of ERBB2 mutations on in vitro sensitivity of bladder cancer to lapatinib," Cancer Biology and Therapy, vol. 15, no. 9, pp. 1239-1247, 2014.

[107] J. Zhao, W. Xu, Z. Zhang et al., "Prognostic role of HER2 expression in bladder cancer: a systematic review and metaanalysis," International Urology and Nephrology, vol. 47, no. 1, pp. 87-94, 2014.

[108] F. H. Groenendijk, J. de Jong, E. E. F. van de Putte et al., "ERBB2 mutations characterize a subgroup of muscle-invasive bladder cancers with excellent response to neoadjuvant chemotherapy," European Urology, 2015.

[109] J. Tschui, E. Vassella, N. Bandi et al., "Morphological and molecular characteristics of HER2 amplified urothelial bladder cancer," Virchows Archiv, vol. 466, no. 6, pp. 703-710, 2015.

[110] K. Izumi, Y. Li, H. Ishiguro et al., "Expression of UDPglucuronosyltransferase $1 \mathrm{~A}$ in bladder cancer: association with prognosis and regulation by estrogen," Molecular Carcinogenesis, vol. 53, no. 4, pp. 314-324, 2014.

[111] L. Giuliani, M. Ciotti, A. Stoppacciaro et al., "UDP-glucuronosyltransferases 1A expression in human urinary bladder and colon cancer by immunohistochemistry," Oncology Reports, vol. 13, no. 2, pp. 185-191, 2005.

[112] T. Kawahara, H. Ide, E. Kashiwagi et al., "Silodosin inhibits the growth of bladder cancer cells and enhances the cytotoxic activity of cisplatin via ELK1 inactivation," American Journal of Cancer Research, vol. 5, no. 10, pp. 2959-2968, 2015.

[113] N. Gonzalez-Roibon, R. Albadine, R. Sharma et al., "The role of GATA binding protein 3 in the differential diagnosis of collecting duct and upper tract urothelial carcinomas," Human Pathology, vol. 44, no. 12, pp. 2651-2657, 2013.

[114] M. B. Amin, K. Trpkov, A. Lopez-Beltran, and D. Grignon, "Best practices recommendations in the application of immunohistochemistry in the bladder lesions: report from the International Society of Urologic Pathology Consensus Conference," American Journal of Surgical Pathology, vol. 38, no. 8, pp. e20-e34, 2014.

[115] L. Verduin, M. J. Mentrikoski, C. T. Heitz, and M. R. Wick, "The utility of GATA3 in the diagnosis of urothelial carcinomas with variant morphologic patterns," Applied Immunohistochemistry \& Molecular Morphology, In press.

[116] Y. Li, H. Ishiguro, T. Kawahara, E. Kashiwagi, K. Izumi, and H. Miyamoto, "Loss of GATA3 in bladder cancer promotes cell migration and invasion," Cancer Biology and Therapy, vol. 15, no. 4, pp. 428-435, 2014.

[117] H. Miyamoto, K. Izumi, J. L. Yao et al., "GATA binding protein 3 is down-regulated in bladder cancer yet strong expression is an independent predictor of poor prognosis in invasive tumor," Human Pathology, vol. 43, no. 11, pp. 2033-2040, 2012.

[118] J.-W. Hsu, I. W. Hsu, D. Xu et al., "Decreased tumorigenesis and mortality from bladder cancer in mice lacking urothelial androgen receptor," The American Journal of Pathology, vol. 182, no. 5, pp. 1811-1820, 2013. 


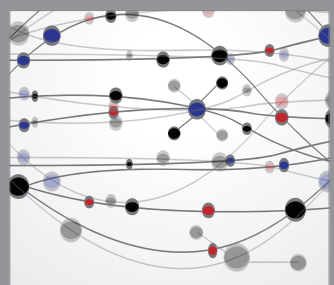

The Scientific World Journal
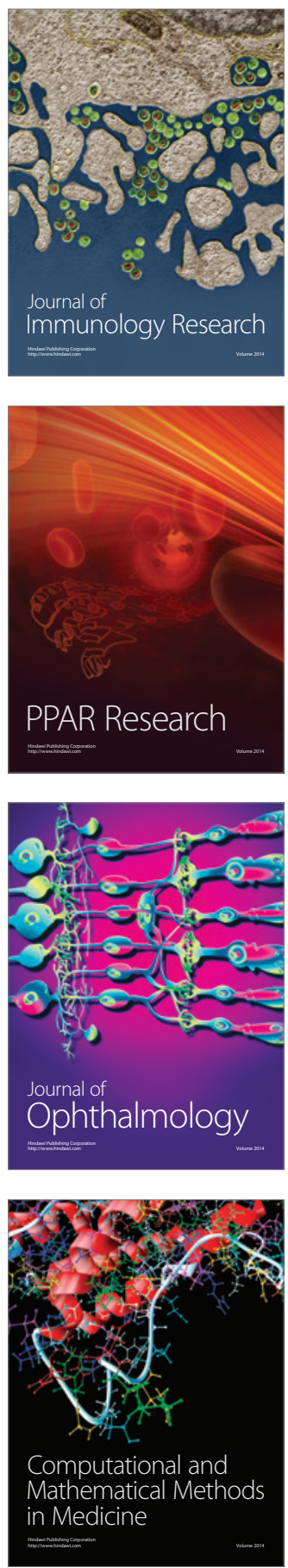

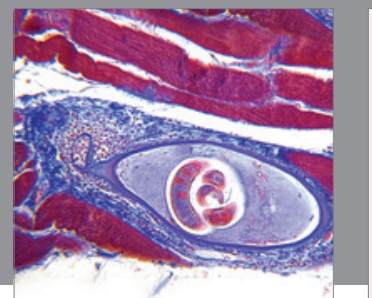

Gastroenterology

Research and Practice
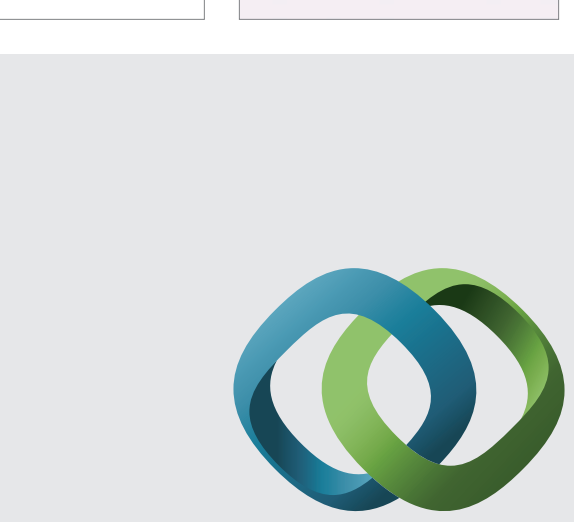

\section{Hindawi}

Submit your manuscripts at

http://www.hindawi.com
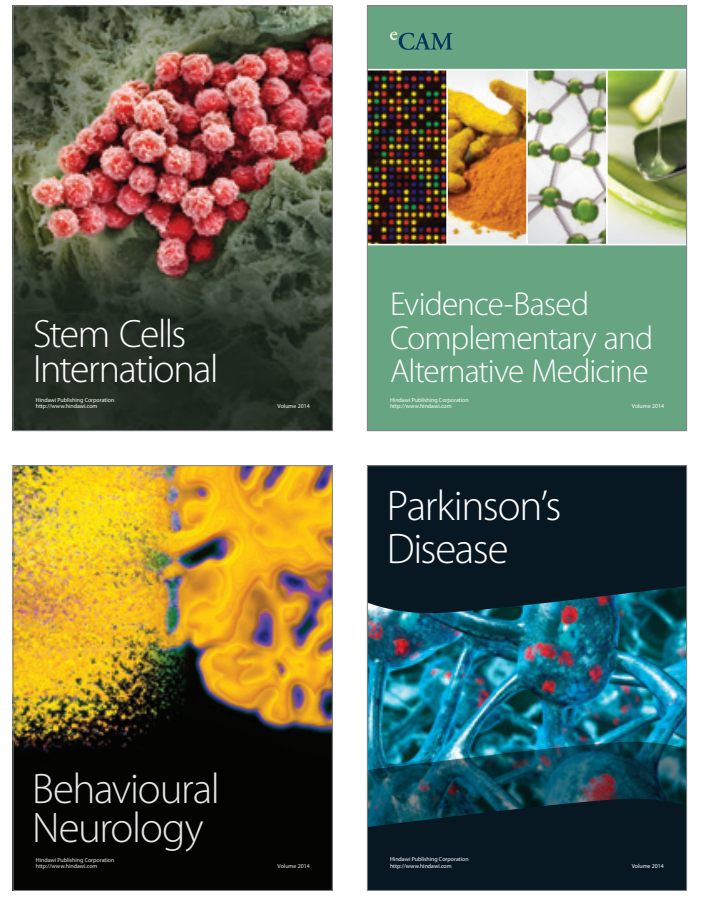
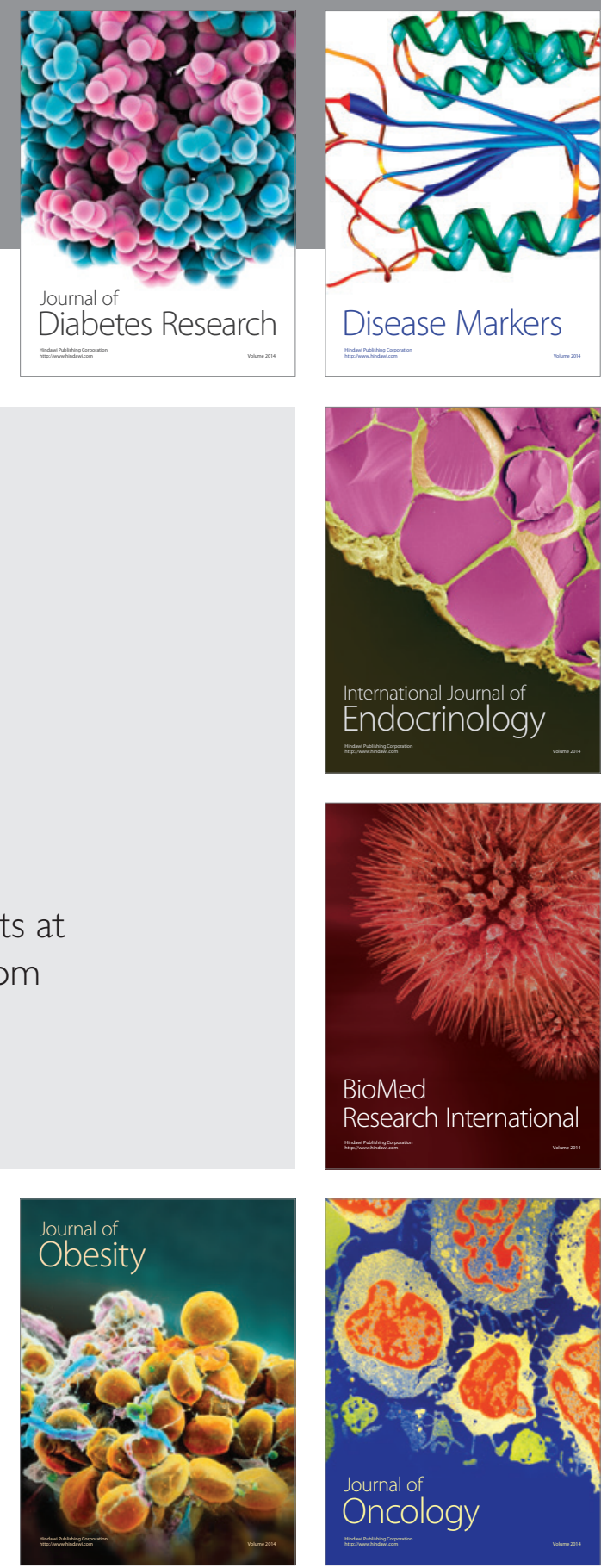

Disease Markers
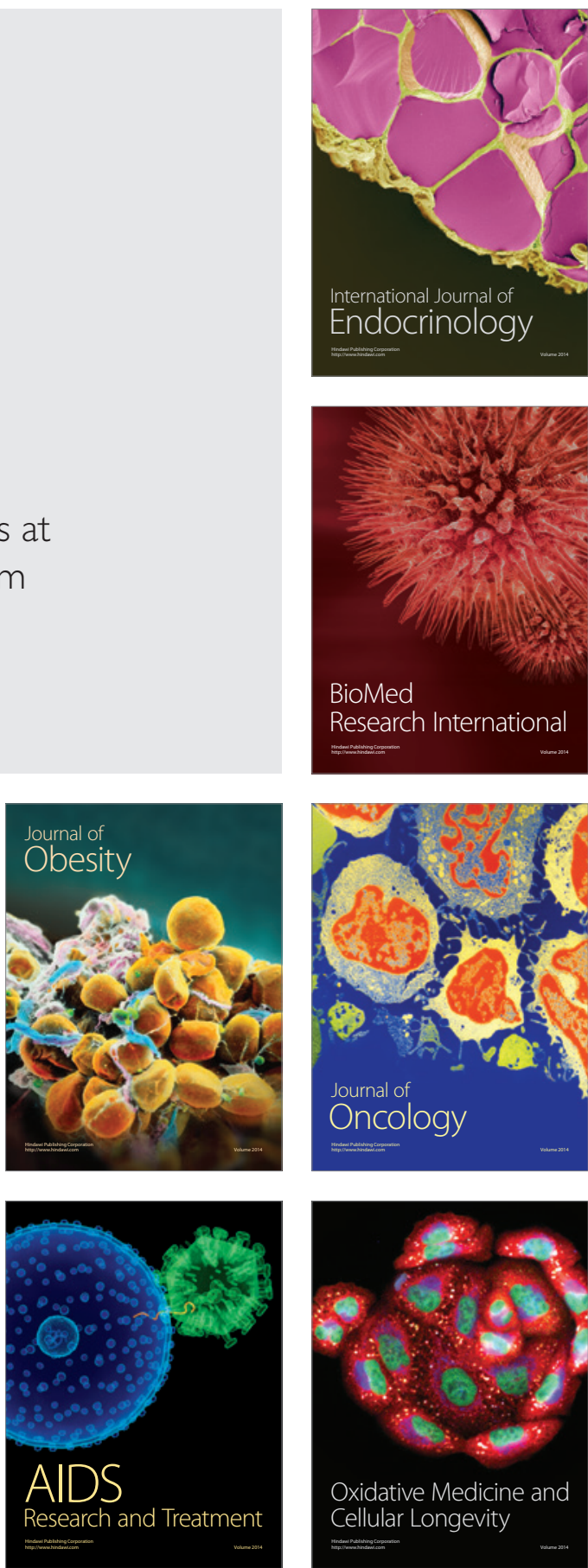